\title{
Effect of temperature on the life cycle of Acanthagrion Selys, 1876 (Insecta: Coenagrionidae) under artificial conditions
}

\author{
João Ânderson Fulan ${ }^{1,5}$, Marcelo Rodrigues dos Anjos ${ }^{1,2,3}$ \& Nadja Gomes Machado ${ }^{3,4}$ \\ ${ }^{1}$ Universidade Federal do Amazonas, Instituto de Educação, Agricultura e Ambiente, Rua 29 de Agosto, \\ 786, Centro, CEP: 69800-000, Humaitá, AM, Brazil. \\ ${ }^{2}$ Universidade Federal do Amazonas, Instituto de Educação, Agricultura e Ambiente, Laboratório de \\ Ictiologia e Ordenamento Pesqueiro do Vale do Rio Madeira, Rua 29 de Agosto, 786, Centro, \\ CEP: 69800-000, Humaitá, AM, Brazil. \\ ${ }^{3}$ Universidade Federal de Mato Grosso, Programa de Pós-Graduação em Física Ambiental, Av. Fernando \\ Corrêa da Costa, 2367, Bairro Boa Esperança, CEP: 78060-900, Cuiabá, MT, Brazil. \\ ${ }^{4}$ Instituto Federal de Mato Grosso, Laboratório de Biologia da Conservação, Avenida Juliano Costa \\ Marques, s/n, Bela Vista,CEP: 78050-560, Cuiabá, MT, Brazil. \\ ${ }^{5}$ Corresponding author: João Ânderson Fulan, e-mail: joaofulan@hotmail.com
}

FULAN, J.A., ANJOS, M.R., MACHADO, N.G. Effect of temperature on the life cycle of Acanthagrion Selys, 1876 (Insecta: Coenagrionidae) under artificial conditions. Biota Neotropica. 15(2): e20140169. http://dx.doi.org/10.1590/1676-06032015016914

\begin{abstract}
The goal of this study was to investigate the effect of temperature on the life cycle of Acanthagrion nymphs sampled in a stream in the southern state of Amazonas. Altogether, 50 nymphs (10 in each of the five treatments) with ambient temperatures of $16,20,24,28$ and $32^{\circ} \mathrm{C}$ and water temperatures of $18,22,26,30$ and $34^{\circ} \mathrm{C}$, respectively, were used. The only treatment that had a hatching adult was at a temperature of $28^{\circ} \mathrm{C}$, identified in a single species, Acanthagrion apicale. In all other treatments $\left(16,20,24\right.$ and $\left.32^{\circ} \mathrm{C}\right)$, all nymphs died, respectively $1,1,3$ and 2 days. We conclude from the results of this study that controlling water temperature near $28^{\circ} \mathrm{C}$ was the most efficient for obtaining adult A. apicale, and that this temperature was close to the average temperature where the nymphs were sampled, indicating that the control of this variable in artificial conditions is extremely important to obtain adults from nymphs.
\end{abstract}

Keywords: Insecta, nymphs, temperature.

FULAN, J.A., ANJOS, M.R., MACHADO, N.G. Efeito da temperatura sobre o ciclo de vida de Acanthagrion Selys, 1876 (Insecta: Coenagrionidae). Biota Neotropica. 15(2): e20140169. http://dx.doi. org/10.1590/1676-06032015016914

Resumo: O objetivo deste trabalho foi investigar o efeito da temperatura sobre o ciclo de vida das ninfas de Acanthagrion amostradas em um igarapé no sul do estado do Amazonas. Ao todo foram utilizadas 50 ninfas (10 em cada um dos cinco tratamentos) com temperaturas ambiente de $16,20,24,28$ e $32^{\circ} \mathrm{C}$ e temperaturas da água de $18,22,26,30$ e $34^{\circ} \mathrm{C}$, respectivamente. $\mathrm{O}$ único tratamento em que houve a eclosão do adulto foi à temperatura de $28^{\circ} \mathrm{C}$ e foi identificada uma única espécie Acanthagrion apicale. Em todos os outros tratamentos $\left(16,20,24\right.$ e $\left.32^{\circ} \mathrm{C}\right)$ todas as ninfas morreram, respectivamente, em $1,1,3 \mathrm{e}$ 2 dias. Concluímos a partir dos resultados deste estudo que o controle de temperatura da água próximo a $28^{\circ} \mathrm{C}$ foi o mais eficiente para obtenção do adulto de $A$. apicale e que esta temperatura ficou próxima da temperatura média do local onde as ninfas foram amostradas indicando que o controle desta variável em condições artificiais é extremamente importante para a obtenção dos adultos a partir das ninfas.

Palavras-chave: Insecta, ninfas, temperatura.

\section{Introduction}

Studies involving Odonata have become very common in recent years (Corbet 1999). Odonata are commonly observed in aquatic ecosystems, however, the rearing of nymphs in the laboratory allows researchers to control environmental variables such as temperature, which is difficult to monitor in natural conditions (Locklin et al. 2012).

The effect of temperature on Odonata is well known (Hassall $\&$ Thompson 2008). The temperature limits their distribution and also changes their behavior (Corbet 1999). Some Odonata species exhibit temperature adaptations and are able to maintain their temperature constant, in comparison to the environment, showing certain endothermic regulation (May 1976).

Laboratory experiments conducted at constant temperatures showed success in the rearing of Anax junius (Drury 1770) nymphs (Trottier 1971). The rearing of Odonata nymphs in laboratory experiments is essential to obtain adults and species identification. In Brazil, there are very few studies involving the life cycles of species, especially in Amazonas species. 


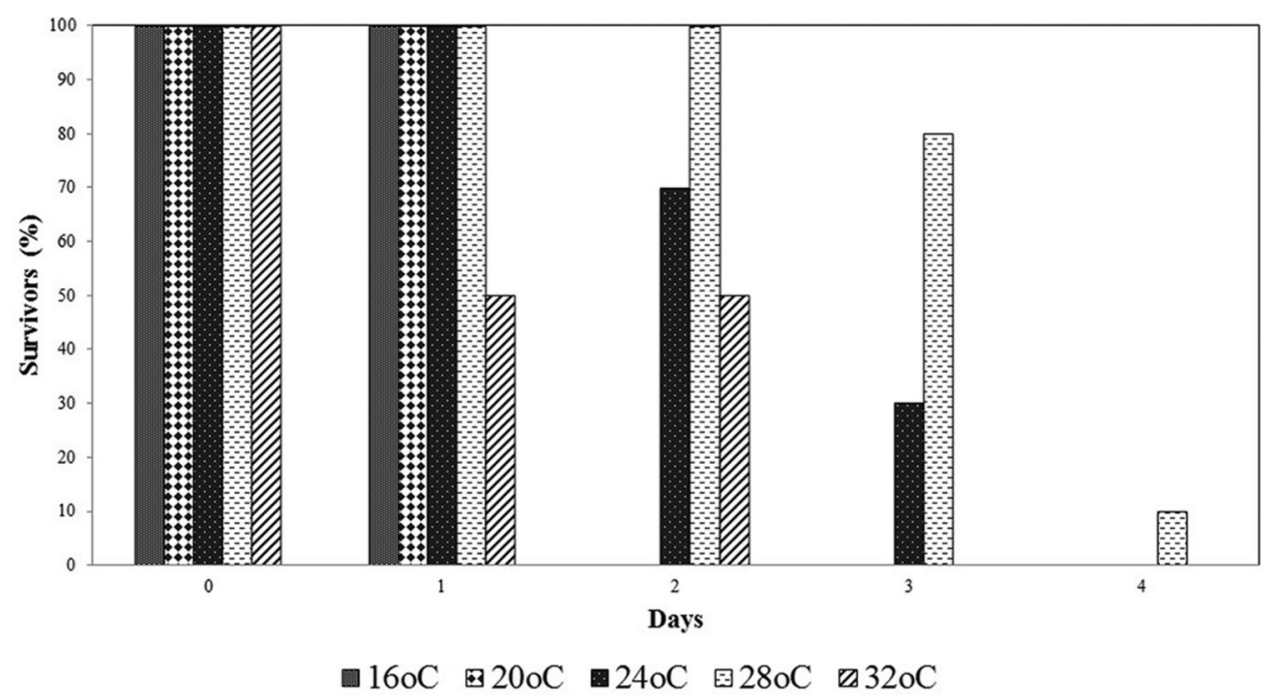

Figure 1.

The objective of this study was to investigate the effects of the temperature on the life cycle of Acanthagrion Selys 1876 reared in laboratory conditions in order to identify the most suitable temperature for the attainment of adults, thereby increasing efficiency in the creation of the nymphs.

\section{Material and Methods}

All nymphs were obtained from the root of aquatic plant Eichhornia azurea (Sw.) from July 2013 to August 2013 in a creek in Humaitá, Amazonas State, Brazil (07³1'06'S and $\left.63^{\circ} 00^{\prime} 58^{\prime \prime} \mathrm{W}\right)$. Ten nymphs in the penultimate or final instar were used in the experiment in each treatment. The nymphs were fed exclusively on Chironomidae (Diptera). Acanthagrion nymphs were grown in plastic trays $(30 \times 20 \times 7.5 \mathrm{~cm})$ covered by a screen of $0.25 \mathrm{~mm}$ and $2 \mathrm{~cm}$ of water. Ten trays were used for each treatment and each tray had only one Acanthagrion nymph per tray to prevent intraspecific predation. Five treatments were performed in the laboratory with external temperatures of $18,22,26,30$ and $34^{\circ} \mathrm{C}$.

\section{Results}

The average water temperatures in the sites sampled were about $16,20,24,28$ and $32^{\circ} \mathrm{C}$, and the external temperatures (laboratory) of $18,22,26,30$ and $34^{\circ} \mathrm{C}$, respectively. The results were discussed in relation to water temperature because this is where the larvae come into direct contact. The only treatment which had the emergence of the adult was at a temperature of 28 C. It was at this temperature that the only adult species, Acanthagrion apicale Selys, 1876 was obtained. In all other treatments $\left(16,20,24\right.$ and $\left.32^{\circ} \mathrm{C}\right)$, all nymphs died, respectively 1, 1, 3 and 2 days (Fig. 1).

\section{Discussion}

Low water temperatures may increase stress during the development of Odonata nymphs (Chang et al. 2007, Thompson \& Hassall 2008). In this work, when we analyzed the water temperature in the different treatments, a higher mortality rate of the Acanthagrion nymphs was recorded in temperatures of
16 and $20^{\circ} \mathrm{C}$ water, showing that warmer temperatures had a negative effect on their life cycle. On the other hand, the higher water temperatures of $32^{\circ} \mathrm{C}$ in the treatment was also responsible for the death of $100 \%$ of nymphs between the 2 nd and 3rd days of the experiment. The negative effect of increased temperature on the physiology of the Odonata nymph as its life cycle, the rate of development of nymphs and its immune system is recognized (Hassall \& Thompson 2008). Acanthagrion nymphs were sampled in a stream in southern Amazonas where the ambient temperature can reach over $40^{\circ} \mathrm{C}$. The water temperature at the sampling nymph site, along with macrophytes, was never higher than $30^{\circ} \mathrm{C}$, with an average holding temperature of $28,3^{\circ} \mathrm{C}$. Therefore, we must consider that natural environmental refuge conditions, enabled by macrophytes or a high diversity of prey, among other factors, cannot be reproduced in the laboratory. It's important to emphasize that obtaining the only adult in the experiment was in water temperatures of $28^{\circ} \mathrm{C}$, which is very close to the average water temperature $\left(28,3^{\circ} \mathrm{C}\right)$ where the nymphs were obtained. This result shows the importance of measuring the local temperature where the nymphs are sampled to have success in the creation and acquisition of adult insects. Locklin et al. (2012) succeeded in obtaining Ischnura ramburii (Selys) nymphs from adults in an average temperature of $25.4^{\circ} \mathrm{C}$. I. ramburii, as well as Acanthagrion, belong to the same Coenagrionidae family, so at least in artificial conditions, temperatures of $25^{\circ} \mathrm{C}$ to $28^{\circ} \mathrm{C}$ seem to be important to complete the life cycle of at least these two genres. However, it is also necessary to consider that the 50 Acanthagrion nymphs used in this experiment may be of different species. Unfortunately, it is not possible to identify the species from nymphs, so it is possible that other nymphs of the same genus have different environmental needs which, unfortunately, could not be detected because in this experiment we were only able to identify a single species, $A$. apicale. The nymphs that died during the experiment could not be identified to species level.

We conclude from the results of this study that controlling water temperature to near $28^{\circ} \mathrm{C}$ was the most efficient for obtaining adult $A$. apicale and that this temperature was close to the average temperature where the nymphs were sampled, indicating that the control of this variable in artificial conditions is extremely important to obtain adults from nymphs. 


\section{Acknowledgements}

This work was funded by Conselho Nacional de Desenvolvimento Científico e Tecnológico (Proc. 471465/2011-9).

\section{References}

CHANG, X., ZHAI, B., LIU, X. \& WANG, M. 2007. Effects of temperature stress and pesticide exposure on fluctuating asymmetry and mortality of Copera annulata (Selys) (Odonata: Zygoptera) larvae. Ecotox. Environ. Safe. 67: 120-127.

CORBET, P.S. 1999. Dragonflies: Behavior and Ecology. Cornell University Press, New York.
HASSALL, C. \& THOMPSON, D.J. 2008. The impacts of environmental warming on Odonata: a review. Int. J. Odonatol. 11:131-153.

LOCKLIN, J.L., HUCKABEE, J.S. \& GERING, E.J. 2012. A method for rearing large quantities of the damselfly, Ischnura ramburii (Odonata: Coenagrionidae), in the laboratory. Fla. Entomol. 95(2): 273-277, doi: http://dx.doi.org/10.1653/024.095.0205.

MAY, M.L 1976. Thermoregulation and Adaptation to Temperature in Dragonflies (Odonata: Anisoptera). Ecol. Monogr. 46: $1-32$.

TROTTIER, R. 1971. Effect of temperature on the life-cycle of Anax junius (Odonata: Aeshnidae) in Canada. Canad. Entomol. 103:1671-1683. 